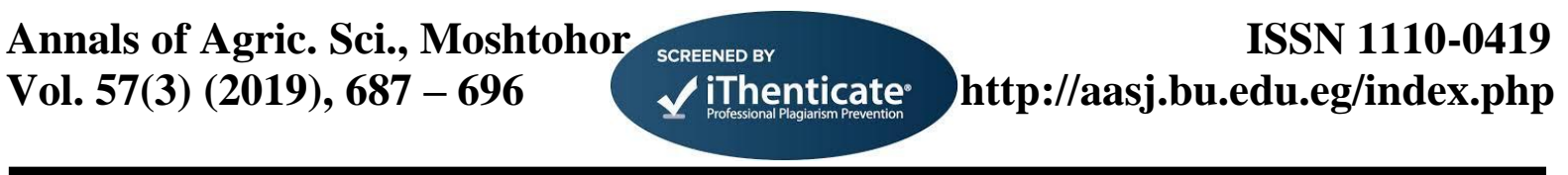

\title{
Effect of ajwainseeds on pan bread quality
}

\author{
Hanaa A.R. Mohamed a , Y.I.Sallam ${ }^{\text {b }}$, A.S.El-Leithy ${ }^{\mathrm{c}}$ and SafaaE.Aly ${ }^{\mathrm{a}}$ \\ ${ }^{\text {a }}$ Food Technology Research Institute, Giza, Egypt \\ ${ }^{\mathrm{b}}$ Food Technology Dept., Fac. of Agric., Cairo Univ., Giza, Egypt \\ ${ }^{\mathrm{c}}$ Orn. Hort. Dept., Fac. of Agric., Cairo Univ., Giza, Egypt \\ Corresponding author: hanaa.ahmed1981@yahoo.com
}

\begin{abstract}
The aim of this study was to evaluate the effect of ajwain seeds (TrachyspermumammiL.) and its essential oil on pan bread quality. Ajwain seeds yielded $2.8 \%$ essential oil. Thymol (35.80\%) followed by $\rho$-cymene (34.76\%) and $\gamma$-terpinene $(19.20 \%)$ were identified as major constituents of the essential oil. Powder of ajwain was used at 2,4 and $6 \%$ of wheat flour (w/w), while ajwain oil incorporated at $200 \mu \mathrm{l} / 4 \mathrm{~g}$ sunflower. Only replacement level at $6 \%$ was unacceptable by consumer panelists. No significant differences were observed in specific volume and hardness in all tested samples either contained different ajwain powder levels or ajwain essential oil compared with control. The only observed differences ( $\mathrm{p}<.05$ ) was in specific volume of treatment $\mathrm{A}_{4}$ which containing $4 \%$ ajwain powder. Specific volume of pan bread was ranged between $4.11 \mathrm{~cm}^{3} / \mathrm{g}$ for control bread without any addition $C_{0}$ to $3.89 \mathrm{~cm}^{3} / \mathrm{g}$ for $\mathrm{A}_{4}$ treatment. Whereas, hardness values ranged between 7.50 and $7.73 \mathrm{~N}$. for samples $\mathrm{C}_{0}$ and $\mathrm{A}_{4}$, respectively. Crumb color was significantly affected $(\mathrm{p}<.05)$, by increasing replacement level, $\mathrm{L}^{*}$ values were decreased while, $b^{*}$ and $a^{*}$ values increased. These means the darkness gradually increased, and yellowness decreased. Ajwain seeds power at $2 \%$ and $4 \%$ exhibited good antimicrobial activity until the seventh day of storage, as also observed for positive control. While, shelf life of pan bread without any addition $\mathrm{C}_{0}$ was not excessed three days, and five days for $A_{E}$ sample which contain ajwain essential oil.
\end{abstract}

Key words: Ajwain, Pan bread quality, Shelf life, Essential oils, Physical properties.

\section{Introduction}

According to the Codex Alimentarius, bread is the product resulting from baking dough obtained by mixing flour and water, with or without addition of edible salt, fermented bakery's yeast (Heras-Mozoset al., 2019).Among bakery products, pan bread is one of common consumed product worldwide. Like to any processed food, the shelf life of bread is reduced due to many causes such as microbial growth(Mani López et al., 2018). There are several methods to extend shelf life of bakery products, propionic acid and its salts are the most common synthetic preservative had been used. The growing demand of consumers for safe products without addition of chemical preservative has led to more attention to aromatic plants which generally recognize as safe (GRAS)(Lucera et al., 2012). One of these valuable plants is ajwain seeds as powder and/or its essential oil.

Ajwain(TrachyspermumammiL.)is an annual herbaceous flowering plant belong to family Apiaceae, which grows worldwide in arid and semiarid regions, including Egypt (Niazianet al., 2019). Ajwain seeds had essential oil known to be active and effective as anti-fungal, anti-bacterial and anti-oxidant agent (Kavoosiet al., 2013; Boskabadyet al., 2014;Zarshenaset al., 2014; Snoussiet al., 2018 and Attouet al., 2019).

Literature searches were undertaken on the effect of addition medicinal and aromatic plants and their extracts on bakery products quality. For example, the effects of grape seed extract (Peng et al., 2010), effect of ginseng powder (Changand $\mathrm{Ng}, 2012$ ), Rubuscoreanus powder (Lee, 2015), effect of black tea (Zhu et al., 2016) and green tea powder (Ninget $a l ., 2019)$. Therefore, the aim of this study was to investigate the effect of ajwain and its essential oil on pan bread quality.

\section{Materials and methods}

\section{Materials:}

Ajwain (Trachyspermumammi (L.) seeds were obtained from Harraz for Food Industry and NaturalProducts, Cairo, Egypt.Wheat flour $72 \%$ extract,instant yeast, salt, sugar and sodium propionate were purchased from the local market. Sunflower oil without synthetic antioxidant was obtained from Armafor Food Industry, $10^{\text {th }}$ of Ramadan City, Egypt.

\section{Methods:}

1. Extraction of ajwain essential oil:

Hundred grams of dried plantswere subjected to hydro-distillation using Clevenger-type apparatus, for $3: 4 \mathrm{hr}$.according to the method recommended in British Pharmacopoeia (2007). The extracted essential oil was dried using anhydrous sodium sulfate and stored in dark and sealed bottles in a refrigerator at $4^{\circ}$ $\mathrm{C}\left( \pm 2{ }^{\circ} \mathrm{C}\right)$.

\section{GC/MS analysis of ajwain essential oil:}

GC-MS analyses were carried out using the methods described by Mihajilov-Krstevet al., (2009). 
CapillaryGC-2010 plus Gas Chromatographs (Shimadzu Corp., Japan), coupled with Shimadzu FID 2010 plus detector (Flame Ionization Detector). The GC system was equipped with a Stabilwax column (30 $\mathrm{m} \times 0.25 \mathrm{~mm}$ i.d., film thickness $0.25 \mu \mathrm{m}$ ); oven temperature was $40^{\circ}-150^{\circ} \mathrm{C}$ at a rate of $4^{\circ} \mathrm{C} / \mathrm{min}$ and held for $6 \mathrm{~min}$; rising at $4^{\circ} \mathrm{C} / \mathrm{min}$ to $210^{\circ} \mathrm{C}$ and held for 1 min., carrier gas was Helium with a flow rate $1 \mathrm{~mL} / \mathrm{min}$, split ratio $1: 10$. The injector and detector were held at $210^{\circ} \mathrm{C}$ and $250^{\circ} \mathrm{C}$, respectively. The obtained chromatogram and analysis report were analyzed to calculate the percentage of the main volatile compounds.

\section{Preparation and formulation of pan bread samples:}

The straight dough method for pan bread production was carried out according to the method described by (AACC, 2002) with some modification at Special Unit for Bakery Products Food Technology Research Institute (FTRI), Giza, Egypt.
Basic dough formula of $1000 \mathrm{~g}$ flour basis was consisted of instant yeast $(15 \mathrm{~g})$, sugar (20 g), salt $(12 \mathrm{~g})$, sunflower oil $(4 \mathrm{~g})$ and the required amount of water. The blends of wheat flour with three levels of ajwain powder i.e. 20, 40, $60 \mathrm{gm}$ or with $200 \mu \mathrm{l}$ essential oil as shown in Table (1).All other ingredients were mixed together. The resulted dough was let to rest for $30 \mathrm{~min}$ (first proofing), then divided to $(350 \mathrm{gm})$ pieces, rolled and molded in molding. Each piece was placed in baking pans $(28 \times 12 \times 7 \mathrm{~cm})$ tightly greased to prevent the loaves from sticking pans and was let to ferment for $60 \mathrm{~min}$ in a cabinet at $30^{\circ} \mathrm{C}$ and $80-85 \%$ relative humidity, then baking process was carried out in electrically heated oven at $230^{\circ} \mathrm{C}$ for $25-30 \mathrm{~min}$. After baking, loaves were separated from the baking pans and allowed to cool for $2 \mathrm{hr}$. at room temperature $\left(28^{\circ} \mathrm{C} \pm 5^{\circ} \mathrm{C}\right)$ for physical and organoleptic evaluation. The produced loaves were weighted, and the volume was measured by the rapeseed displacement method according to (AACC, 2002).

Table 1. Ingredients of pan bread

\begin{tabular}{|c|c|c|c|c|c|c|c|}
\hline \multirow[b]{2}{*}{ Sample } & \multirow[b]{2}{*}{$\begin{array}{l}\text { Flour } \\
\text { (g) }\end{array}$} & \multicolumn{2}{|c|}{ Ajwain } & \multirow[b]{2}{*}{$\begin{array}{c}\text { Yeast } \\
(\mathrm{g})\end{array}$} & \multirow[b]{2}{*}{$\begin{array}{c}\text { Sunflower } \\
\text { oil (g) }\end{array}$} & \multirow[b]{2}{*}{$\begin{array}{c}\text { Salt } \\
(\mathrm{g})\end{array}$} & \multirow[b]{2}{*}{$\begin{array}{c}\text { Sugar } \\
\text { (g) }\end{array}$} \\
\hline & & $\begin{array}{c}\text { powder } \\
\text { (g) }\end{array}$ & $\begin{array}{c}\text { Essential } \\
\text { oil }\end{array}$ & & & & \\
\hline $\begin{array}{l}\mathrm{C}_{0} \\
\text { Control (-) }\end{array}$ & 1000 & - & & 15 & 4 & 12 & 20 \\
\hline $\begin{array}{l}\mathrm{C}_{1} \\
\text { Control (+) }\end{array}$ & $\begin{array}{l}1000+\text { sodium } \\
\text { propionate } \\
(0.2 \%)\end{array}$ & & & 15 & 4 & 12 & 20 \\
\hline $\mathbf{A}_{2}$ & 980 & 20 & & 15 & 4 & 12 & 20 \\
\hline $\mathbf{A}_{4}$ & 960 & 40 & & 15 & 4 & 12 & 20 \\
\hline$A_{6}$ & 940 & 60 & & 15 & 4 & 12 & 20 \\
\hline $\mathbf{A}_{E}$ & 1000 & - & $200 \mu 1$ & 15 & 4 & 12 & 20 \\
\hline
\end{tabular}

${ }^{*} \mathrm{C}_{0}$ : Control bread without any addition; $\mathrm{C}_{1}$ : Control bread with synthetic preservative (sodium propionate); $\mathrm{A}_{2}$, $\mathrm{A}_{4}$ and $\mathrm{A}_{6}$ : pan bread contains ajwain seed powder $2 \%, 4 \%$ and $6 \%$ respectively; $\mathrm{A}_{\mathrm{E}}$ : pan bread contains ajwain seed essential oil at $200 \mu 1$.

\section{Overall acceptability}

A seven-point hedonic scale was used to evaluate the overall acceptability of the bread formulations; where 1 = dislike very much, 2 = dislike moderately, $3=$ dislike slightly, $4=$ neither like nor dislike, $5=$ like slightly, $6=$ like moderately and $7=$ like very much as suggested by Wójciket al., (2017), to determine the acceptable levels of replacement. Breads were considered acceptable if their mean scores for overall acceptability were above 4 (neither like nor dislike).

\section{Sensory evaluation}

The Organoleptic characteristics of the pan bread attributes were evaluated by fifteen panelists of Food Technology Research Institute (FTRI) for color (20), taste (20), odor (20), appearance (20) and texture (20) according toSeleemet al., (2014).

\section{Physical properties of pan bread}

a. Specific volume of pan bread loaves

After baking and cooling for $2 \mathrm{hr}$. The bread volume was measured according to the method of (AACC, 2002), weights were recorded by using decimal digital weighing scale. The specific volume was calculated as the ratio between the volume and the weight of the bread $\left(\mathrm{cm}^{3} / \mathrm{g}\right)$. Three replicates of each sample were analyzed.

\section{b. Texture profile analysis (TPA)}

Texture parameter (hardness) of pan bread samples was measured objectively by using a texture analyzer CT3 Texture Analyzer (Version 2.1, 10000 Gram unit, Brookfield, Engineering Laboratories, Inc. USA), according to method 74-09 (AACC, 2000)and as describe by Peng et al., (2010) with some modifications. Whereas one slice of pan bread approximately $25 \mathrm{~mm}$ thick or two slices, each approximately $12.5 \mathrm{~mm}$ thick could be used. Set up a $36 \mathrm{~mm}$ diameter cylindrical probe at a test speed of 2 
$\mathrm{mm} / \mathrm{s}$. The location of testing was the center of the bread slices avoiding non-representative areas of crumb. Sample was subjected to $40 \%$ deformation and trigger load 5g. Parameters (graph and data) were automatically recorded by computer software (TACT-PRO Software). Test was a total of three samples per treatment undergo. Results were calculated as the average of the three determinations per treatment.

\section{c. Color measurement}

The color (CIE* system) of pan bread crumb were determined using a Chroma-meter (Minolta CR-400, Minolta, Osaka, Japan) according to the method of Zhu et al., (2016). Where, L* indicates the brightnessdarkness. While positive and negative $\mathrm{a}^{*}$ indicates the redness-greenness and $b^{*}$ indicates yellownessblueness. For a comprehensive analysis comparing $\mathrm{L}^{*}, \mathrm{a}^{*}$ and $\mathrm{b}^{*}$ values together, $E$ index was calculated using the following equation:

$E=\left(\mathrm{L}^{* 2}+\mathrm{a}^{* 2}+\mathrm{b}^{* 2}\right)^{1 / 2}$ as mentioned by Peng et al., (2010).

\section{Microbial evaluation of pan bread loaves}

The microbial evaluation of pan bread loaves includes; total bacterial count (TBC), yeasts and mold counts.Cell counts were performed by plating of serial dilutions of the pan bread homogenates at 0,4 and 7 days of storage at room temperature according to ISO, (2008). All experiments were carried out in duplicates.

\section{Statistical analysis}

The results were statistically analyzed using CoState statistical software (CoHort Software, Monterey, CA, USA). The statistical calculations included the analysis of variance (ANOVA) one way completely randomized. $\mathrm{p}<0.05$ was considered to be significant using Duncan's test. All data were expressed as means values \pm Standard Deviation (SD), as described bySnedecor and Cochran (1982).

\section{Results and discussion}

\section{The essential oil content of ajwain seeds}

Light brownish essential oil with yield of $2.8 \%$ (on dry weight basis) was obtained from dry ajwain seeds. This findingis in agreement with that obtained byAttouet al.,(2019), who reported that hydrodistillation of dried ajwain seeds yielded $2.58 \%$ (w/w). Also, Zarshenaset al., (2014) mentioned that mean yield of ajwain essential oil obtained from ten samples of dried seeds ranged from $2.2 \%$ to $4.8 \%(\mathrm{v} / \mathrm{w})$. While, Howyzehet al., (2018) found that essential oil of Iranian ajwain yielded $5.7 \%$.

\section{Composition of ajwain essential oil}

The essential oil composition of ajwain seeds was analyzed by GC/MS. Results are shown in Table (2) and are graphically illustrated in Fig. (1). It could be noticed that twelve compounds, representing $98.02 \%$ of total chemical composition, were identified in ajwain (Trachyspermumammi (L.) essential oil. The major constituents were thymol $(35.80 \%)$ followed by $\rho$-cymene $(34.76 \%)$ and $\gamma$-terpinene $(19.20 \%)$. Meanwhile, $\beta$-pinene was detected at $2.65 \%$. These results in the same line with those obtained by Zarshenaset al., (2014) and SoltaniHowyzeh et al., (2018) who found that major constituents of ajwain essential oil were thymol, $\rho$-cymene and $\gamma$-terpinene, and these components were different in ranking amount. While, on another study by Moeinet al., (2015) stated that $\gamma$-terpinene was the major compound $(48.07 \%)$ followed by $\rho$-cymene $(33.73 \%)$ and thymol $(17.41 \%)$.

Table 2. Chemical components of ajwain essential oil

\begin{tabular}{llcc}
\hline No. & Compound & RT & Area \% \\
\hline $\mathbf{1}$ & $\beta$-Thujene & 7.78 & 0.53 \\
$\mathbf{2}$ & $\alpha$-pinene & 7.97 & 0.64 \\
$\mathbf{3}$ & $\beta$-pinene & 9.38 & 2.65 \\
$\mathbf{4}$ & Myrcene & 9.97 & 0.78 \\
$\mathbf{5}$ & $\alpha$-Terpinene & 10.81 & 0.51 \\
$\mathbf{6}$ & -Cymene & 11.20 & 34.76 \\
$\mathbf{7}$ & d-Limonene & 11.29 & 0.95 \\
$\mathbf{8}$ & $\gamma$-Terpinene & 12.41 & 19.20 \\
$\mathbf{9}$ & Trans-Sabinene hydrate & 13.80 & 0.45 \\
$\mathbf{1 0}$ & 2,6-Dimethyl-3,5,7-octatriene-2-ol,E,E- & 16.26 & 1.01 \\
$\mathbf{1 1}$ & Terpiene-4-ol & 16.59 & 0.74 \\
$\mathbf{1 2}$ & Thymol & 20.76 & 35.80 \\
\hline
\end{tabular}




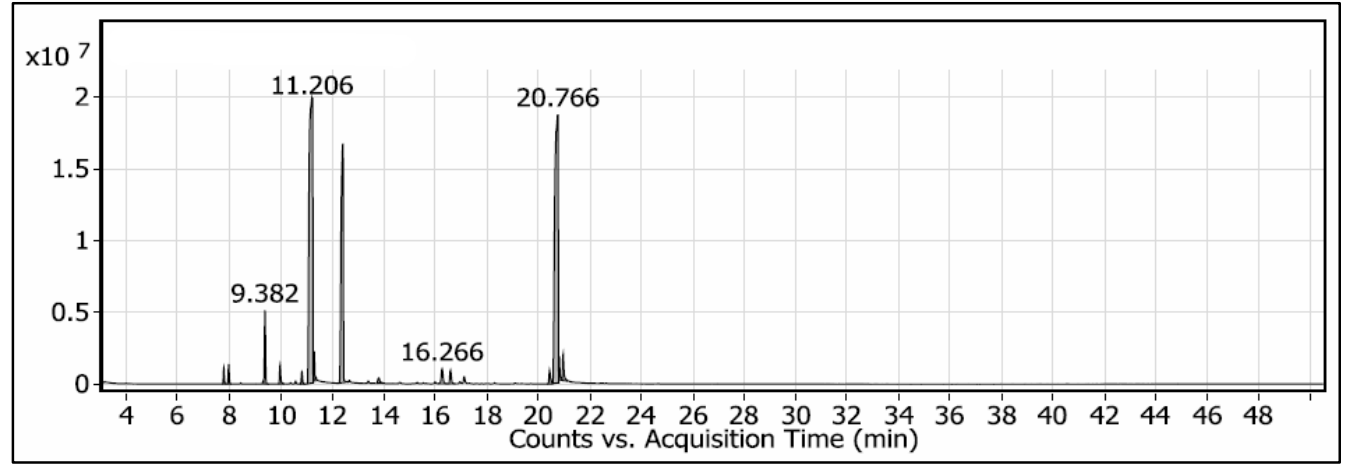

Fig. 1

Chromatogram of ajwain seeds essential oil.

\section{Consumer acceptability of pan bread samples}

The consumer acceptability was conducted to evaluate the acceptable level of ajwain. The results in Table (3)showed that no significant differences were observed in treatments $\mathrm{A}_{2}$ and $\mathrm{A}_{\mathrm{E}}$ comparing to control samples, while there was a significant difference $(\mathrm{p}<0.05)$ between control and $\mathrm{A}_{4}$ and $\mathrm{A}_{6}$ samples.

According to the scores, Table (3) and Fig (2) revealed that pan bread $\mathrm{A}_{6}$ recorded below 4 (neither like nor dislike). Thus, $\mathrm{A}_{6}$ sample was not acceptable by the most of panelists probably due to its strong aroma and its bitter after taste (Limet al., 2011). On the other hand, all tested samples were accepted by panelists according to its score values more than four. Also, Lim et al., (2011) reported that bread which contained $6 \%$ or $8 \%$ turmeric had low significant sensory score in overall acceptability, whereas, partial replacement of wheat flour with up to $4 \%$ turmeric powder in breads provide satisfactory overall consumer acceptability.

Table 3. Consumer acceptability of pan bread samples

\begin{tabular}{lc}
\hline Treatment & Consumer acceptability \\
\hline C $_{0}$ Control $_{(-)}$ & $6.80 \pm 0.41^{\mathrm{a}}$ \\
C $_{1}$ Control $_{(+)}$ & $6.77 \pm 0.45^{\mathrm{a}}$ \\
$\mathbf{A}_{2}$ & $6.33 \pm 0.90^{\mathrm{ab}}$ \\
$\mathbf{A}_{4}$ & $5.80 \pm 1.01^{\mathrm{b}}$ \\
$\mathbf{A}_{6}$ & $2.00 \pm 0.92^{\mathrm{c}}$ \\
$\mathbf{A}_{\mathbf{L}}$ & $6.47 \pm 0.74^{\mathrm{a}}$ \\
\hline LSD & 0.56 \\
\hline
\end{tabular}

${ }^{*} \mathrm{C}_{0}$ : Control bread without any addition; $\mathrm{C}_{1}$ : Control bread with synthetic preservative (sodium propionate); $\mathrm{A}_{2}, \mathrm{~A}_{4}$ and $\mathrm{A}_{6}$ : pan bread contains ajwain seed powder $2 \%, 4 \%$ and $6 \%$ respectively; $\mathrm{A}_{\mathrm{E}}$ : pan bread contains ajwain seed essential oil at 200 $\mu l$.

Means \pm SD. Mean values in the same column with different superscript letters are significantly different $(\mathrm{P}<0.05)$.

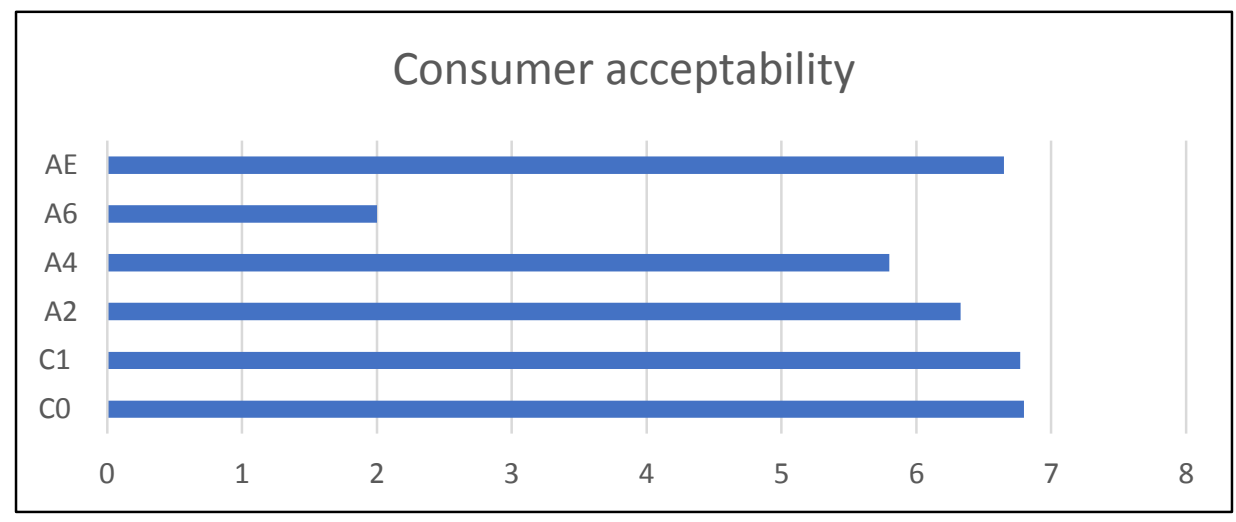

Fig. 2 The overall acceptability of ajwain pan bread samples

\section{Sensory evaluation}

In order to determine the differences in the previously acceptable samples more clearly, the overall quality bread was evaluated for their sensory attributed of taste, color, odor, and texture. The mean scores of the evaluated sensory attributes are presented in Fig (3). 


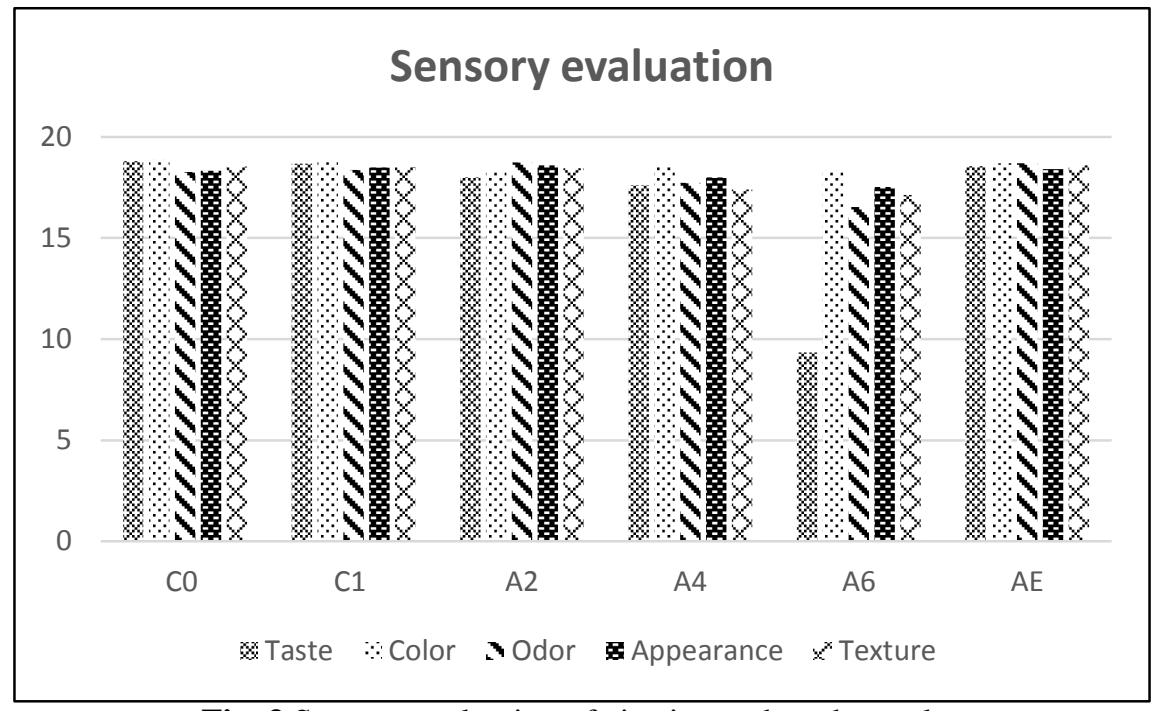

Fig. 3 Sensory evaluation of ajwain pan bread samples

The obtained results showed that no significant differences in all sensory attributes were observed in tested samples either contain $2 \%$ ajwain powder or ajwain essential oil compared with control samples. The significant differences $(\mathrm{p}<0.05)$ was observed in taste of treatments $\mathrm{A}_{4}$ and $\mathrm{A}_{6}$. Whereas, in overall acceptability $\mathrm{A}_{4}$ sample had a good score as mentioned before. These results were closest to those obtained by Bolarinwaet al., (2019) who mentioned that the moringa fortified bread at level 5\% was acceptable to consumer, whereas significant differences were observed in all sensory attributes of bread samples fortified with higher levels of moringa seed powder (> 5\%). The acceptable blends were selected to evaluate the quality characteristics of pan bread.

5. Specific volume and texture profile (hardness) Specific volume of pan bread was ranged between $4.11 \mathrm{~cm}^{3} / \mathrm{g}$ for control $\left(\mathrm{C}_{0}\right)$ to $3.89 \mathrm{~cm}^{3} / \mathrm{g}$ for $\left(\mathrm{A}_{4}\right)$ treatment as shown in Table 4. From the obtained results it could be noticed that the specific volume tends to decrease with increasing replacement levelof ajwain powder or their essential oil. Insignificant differences were observed between control and different treatments. The decreasing of specific volumecould be attributed to the effect of ajwain on gluten network (Schmieleet al., 2012 and Odunladeet al., 2017).

Table 4. Specific volume and hardness of pan bread

\begin{tabular}{lcc}
\hline Treatment & Specific volume $\left(\mathbf{c m}^{3} / \mathbf{g}\right)$ & Hardness $(\mathbf{N})$ \\
\hline $\mathbf{C}_{\mathbf{0}}$ Control $(-)$ & $4.11 \pm 0.10^{\mathrm{a}}$ & $7.50 \pm 0.25^{\mathrm{a}}$ \\
$\mathbf{C}_{1}$ Control $(+)$ & $4.02 \pm 0.18^{\mathrm{a}}$ & $7.59 \pm 0.22^{\mathrm{a}}$ \\
$\mathbf{A}_{2}$ & $3.99 \pm 0.11^{\mathrm{a}}$ & $7.62 \pm 0.24^{\mathrm{a}}$ \\
$\mathbf{A}_{4}$ & $3.89 \pm 0.02^{\mathrm{a}}$ & $7.73 \pm 0.10^{\mathrm{a}}$ \\
$\mathbf{A E}_{\mathbf{L}}$ & $3.95 \pm 0.07^{\mathrm{a}}$ & $7.69 \pm 0.13^{\mathrm{a}}$ \\
\hline $\mathbf{L S D}$ & 0.20 & 0.36 \\
${ }^{*} \mathrm{C}_{0}:$ Control bread without any addition; $\mathrm{C}_{1}:$ Control bread with synthetic preservative (sodium propionate); $\mathrm{A}_{2}, \mathrm{~A}_{4}$ and $\mathrm{A}_{6}:$ pan bread contains \\
ajwain seed powder 2\%, 4\% and 6\% respectively; $\mathrm{A}_{\mathrm{E}}:$ pan bread contains ajwain seed essential oil at $200 \mu 1$. \\
Means \pm SD. Mean values in the same column with different superscript letters are significantly different $(\mathrm{P}<0.05)$.
\end{tabular}

Hardness usually used as an indicator of bread freshness, and negatively correlated with bread quality. The results in Table (4) revealed that hardness values increase slightly by increasing the ajwain powder level and incorporated ajwain essential oil. Whereas, insignificant differences were observed in all treatments contained different ajwain powder levels or ajwain essential oil. Similar increasing trend was observed by other previous studies evaluated the effect of ramie powder (Lee and Joo, 2012) and green tea (Ning et al., 2017). This increasing probably due to interactions between fibers and gluten (Feiliet al.,2013).

\section{Effect of ajwain seeds on pan bread crumb color}

The effect of ajwain seeds powder and its essential oil on pan bread crumb color waspresented in Table 5 . All color data were expressed as L* (lightness darkness), $\mathrm{a}^{*}$ (redness - greenness) and $\mathrm{b}^{*}$ (yellowness - blueness) values. The obtained data revealed that crumb color of pan bread was significantly $(p<0.05)$ affected by replacement level of ajwain powder. From the results it could be noticed that as the level of ajwain increasedthe $\mathrm{L}^{*}$ values significantly decreased, meanwhile $\mathrm{b}^{*}$ and $\mathrm{a}^{*}$ values were increased. These means the darkness gradually 
increased, and yellowness decreased. This finding was in agreement with those obtained by Lee and Joo, (2012) and Zhu et al., (2016).

Table 5. Effect of ajwain on pan bread crumb color

\begin{tabular}{lcccc}
\hline \multirow{2}{*}{ Sample* $^{*}$} & \multicolumn{4}{c}{ Crumb } \\
\cline { 2 - 5 } & $\mathrm{L}^{*}$ & $\mathrm{a}^{*}$ & $\mathrm{~b}^{*}$ & $E$ index \\
\hline CoControl $_{(-)}$ & $78.35 \pm 0.70^{\mathrm{a}}$ & $0.84 \pm 0.07^{\mathrm{c}}$ & $16.55 \pm 1.11^{\mathrm{c}}$ & 80.08 \\
C $_{1}$ Control $_{(+)}$ & $78.47 . \pm 0.12^{\mathrm{a}}$ & $0.85 \pm 0.05^{\mathrm{c}}$ & $16.78 . \pm 0.23^{\mathrm{c}}$ & 80.25 \\
$\mathbf{A}_{2}$ & $68.90 \pm 0.40^{\mathrm{b}}$ & $2.33 \pm 0.11^{\mathrm{b}}$ & $21.28 \pm 0.66^{\mathrm{b}}$ & 72.15 \\
$\mathbf{A 4}_{4}$ & $65.15 \pm 1.29^{\mathrm{c}}$ & $3.16 \pm 0.16^{\mathrm{a}}$ & $23.36 \pm 0.78^{\mathrm{a}}$ & 69.28 \\
$\mathbf{A E}_{\text {LSD }}$ & $78.21 \pm 0.27^{\mathrm{a}}$ & $0.90 \pm 0.05^{\mathrm{c}}$ & $16.78 \pm 0.46^{\mathrm{c}}$ & 79.80 \\
\hline C: & 1.26 & 0.18 & 1.30 &
\end{tabular}

${ }^{*} \mathrm{C}_{0}$ : Control bread without any addition; $\mathrm{C}_{1}$ : Control bread with synthetic preservative (sodium propionate); $\mathrm{A}_{2}, \mathrm{~A}_{4}$ and $\mathrm{A}_{6}$ : pan bread contains ajwain seed powder $2 \%, 4 \%$ and $6 \%$ respectively; $\mathrm{A}_{\mathrm{E}}$ : pan bread contains ajwain seed essential oil at $200 \mu 1$.

Means \pm SD. Mean values in the same column with different superscript letters are significantly different $(\mathrm{P}<0.05)$.

The observed crumb color corresponds mainly to the color of ajwain powder used.On the other hand, the changes of pan bread crumb color of $\left(A_{E}\right)$ treatment showed good color values compared to control samples.

$E$ index was introduced to describe the color changes, compared to control samples $E$ index decreased with replacement level of ajwain powder increased. It means loss in brightness of bread samples. Furthermore, the same trend was also noticed in treatment $A_{E}$ whereas, ajwain essential oil was used.

7. Effect of ajwain seeds on microbial growth of pan bread

The effect of ajwain seeds powder at substituted levels $2 \%$ and $4 \%$ and ajwain oil at concentration
$200 \mu \mathrm{l} / 4 \mathrm{~g}$ sunflower oil on pan bread microbial growth during storage for 7 days at room temperature (28$32^{\circ} \mathrm{C}$ ) compared to control. The obtained results are graphically presented in Fig. 4 samples withoutsodium propionate $\left(\mathrm{C}_{0}\right)$ or with sodium propionate at $0.2 \%\left(\mathrm{C}_{1}\right)$.

Data showed that increasing in Log/CFU count by increasing storage period in all samples. After 3 days, $\mathrm{C}_{0}$ showed a visible fungal growth which indicating the end of shelf life for this sample. This finding is in line with those reported by Seleem and Mohamed (2014).Meanwhile, treatments $\mathrm{C}_{1}, \mathrm{~A}_{2}$ and $\mathrm{A}_{4}$ samples prolonged the shelf life for additional four days compared to $\mathrm{C}_{0}$ sample.

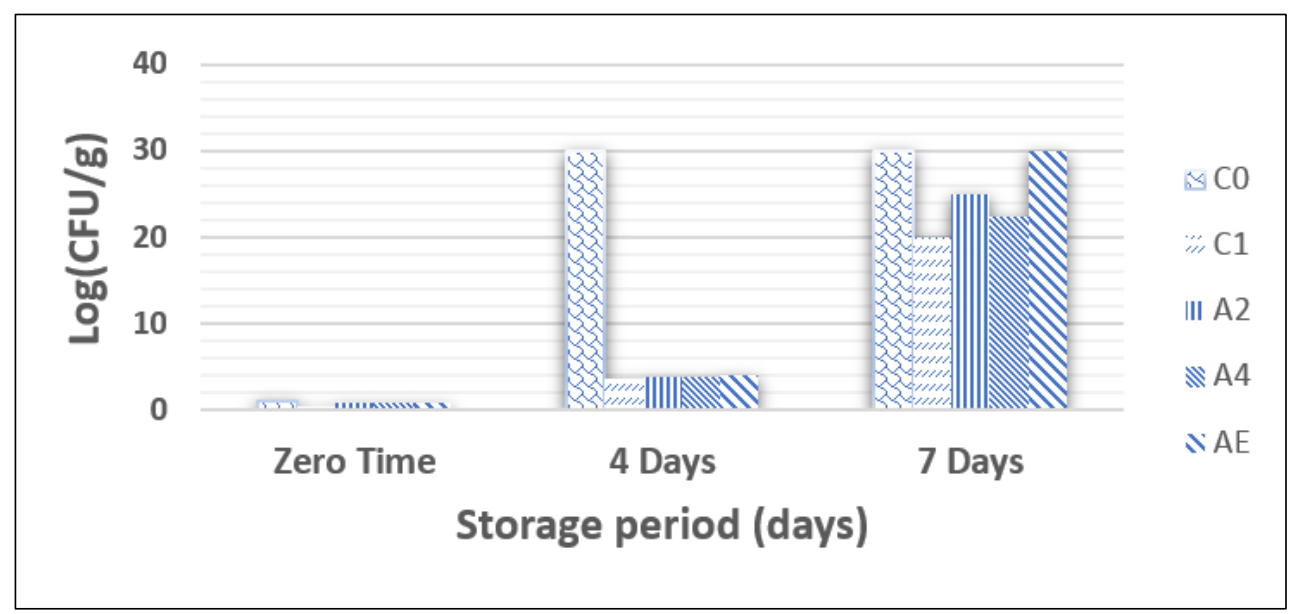

Fig. 4 Microbial growth during storage period

On the other hand, $A_{E}$ exhibited microbial growth after 5 days. Shelf life of $A_{E}$ sample may be extended resulted in advanced techniques as microencapsulation to protect bioactive compound of essential oil. In this respect, Saatchi et al., (2014) found that ajwain essential oil was revealed as efficient antifungal agent. Therefore, it could be concluded that ajwain showed a good antimicrobial activity and able to retard microbial growth in pan bread $(p<0.05)$ for a considerable period of time with good manufactory practice (GMP). 


\section{Conclusion}

In the present study, ajwain seeds powder and its essential oil slightly affected pan bread quality, except at $6 \%$ replacement level where, it was unacceptable by the most panelists probably due to its after taste and strong aroma. Only color characteristics was significantly affected by increasing replacement levels. These changes due to the natural color of ajwain seeds powder. As antimicrobial agent ajwain showed a good antimicrobial activity and able to retard microbial growth in pan bread $(\mathrm{p}<0.05)$ for a considerable period of time.

\section{References}

A.A.C.C. (2000). Approved Methods of the American Association of Cereal Chemists. $10^{\text {th }}$ Ed. Vol. II. A.A.C.C. Methods 74-09. American Association of Cereal Chemists. St. Paul, Minn, USA.

A.A.C.C. (2002).Approved Method of American Association of Cereal Chemists, published by American Association of Cereal Chemists, Ins. St. Paul, Minnesota, USA.

Attou, A.;Davenne, D.;Benmansour, A. and Lazouni, H.A. (2019). Chemical composition and biological activities of Ammoidesverticillata essential oil from west Algeria.Phytothérapie,17(1):2-8.

Bolarinwa, I.F.;Aruna, T.E. and Raji, A.O. (2017). Nutritive value and acceptability of bread fortified with moringa seed powder. J. Saudi Soc. Agric. Sci., 18:195-200.

Boskabady, M.H.;Alitaneh, S. and Alavinezhad, A. (2014). Carumcopticum L.: A herbal medicine with various pharmacological effects.Biomed. Res. Int., 1:1-11.

British Pharmacopeia Commission (2007). British Pharmacopeia Vol. I. The Stationery Office (TSO), London, UK., 3500p.

Chang, Y.H. and Ng, P.K., (2012). Effect of ginseng powder addition on physicochemical properties of wheat bread and cookies. J. Food Sci. Biotechnol., 21(4):951-957.

Feili, R.; Zzaman, W.; Abdullah, W.N.W. and Yang, T.A. (2013). Physical and sensory analysis of high fiber bread incorporated with jackfruit rind flour. Food sci. Technol., 1(2):30-36.

Heras-Mozos, R.; Muriel-Galet, V.; LópezCarballo, G.; Catalá, R.; Hernández-Muñoz, P. and Gavara, R. (2019). Development and optimization of antifungal packaging for sliced pan loaf based on garlic as active agent and bread aroma as aroma corrector. Int. J. Food Microbiol., 290:42-48.

Howyzeh, M.S.; Noori, S.A.S.; Shariati, J.V. and Niazian, M. (2018). Essential oil chemotype of Iranian ajowan (Trachyspermumammi L.). J. Essent. Oil Bear. Plants, 21(1): 273-276.

ISO 21527-1. 2008. Microbiology of food and animal feeding stuffs - Horizontal method for the enumeration of yeasts and moulds - part1: Colony count technique in products with water activity greater than 0.95 .

Kavoosi, G.; Tafsiry, A.; Ebdam, A. A. and Rowshan, V. (2013). Evaluation of antioxidant and antimicrobial activities of essential oils from Carumcopticum seed and Ferulaassafoetida latex. J. Food Sci., 78(2): T356-T361.

Lee, H. andJoo, N. (2012). Optimization of pan bread prepared with ramie powder and preservation of optimized pan bread treated by gamma irradiation during storage. Prev. Nutr. Food Sci., 17:53-63.

Lee, J. H. (2015). Physicochemical and sensory characteristics of sponge cakes with Rubuscoreanus powder.Prev. Nutr. Food Sci., 20(3):204-209.

Lim, H.S.; Park, S.H.; Ghafoor, K.; Hwang, S.Y. and Park, J. (2011). Quality and antioxidant properties of bread containing turmeric (Curcuma longa L.) cultivated in South Korea. Food Chem., 124(4):1577-1582.

Lucera, A.; Costa, C.; Conte, A. and Del Nobile, M.A. (2012). Food applications of natural antimicrobial compounds.Front.Microbiol.,3(287):1-13.

Mani López, E., Valle Vargas, G.P., Palou, E. and López Malo, A. (2018). Penicillium expansum inhibition on bread by lemongrass essential oil in vapor phase.J. Food Prot.,81(3):467-471.

Mihajilov-Krstev, T.;Radnović, D.;Kitić, D.;Zlatković, B.;Ristić, M. and Branković, S. (2009). Chemical composition and antimicrobial activity of Saturejahortensis L. essential oil. Cent. Eur. J. Biol.,4(3):411-416.

Moein, M.R.;Zomorodian, K.;Pakshir, K.;Yavari, F.;Motamedi, M. and Zarshenas, M.M. (2015). Trachyspermumammi (L.) sprague: chemical composition of essential oil and antimicrobial activities of respective fractions.J. Evid-based complementary Altern.Med.,20(1):50-56.

Niazian, M.; Sadat-Noori, S.A.;Tohidfar, M.;Galuszka, P. and Mortazavian, S.M.M. (2019). Agrobacterium-mediated genetic transformation of ajowan (Trachyspermumammi (L.) Sprague): an important industrial medicinal plant.Ind. CropProd.,132:29-40.

Ning, J., Hou, G.G., Sun, J., Zhang, Z. and Wan, X. (2019). Effects of green tea powder on the quality attributes of hard red winter wheat flour and Chinese steamed bread. Inter. J. Food Sci. and Technol., 54(2):576-582.

Ning, J.; Hou, G.G.; Sun, J.; Wan, X. and Dubat, A. (2017). Effect of green tea powder on the quality attributes and antioxidant activity of whole-wheat flour pan bread. LWT-Food Sci. Technol., 79:342-348.

Odunlade, T. V.; Famuwagun, A. A.;Taiwo, K. A.; Gbadamosi, S. O.; Oyedele, D.J. and Adebooye, O.C.(2017). Chemical composition and quality characteristics of wheat bread supplemented with 
leafy vegetable powders. J. Food Quality, 2017:17.https://doi.org/10.1155/2017/9536716

Peng, X.; Ma, J.; Cheng, K.W.; Jiang, Y.; Chen, F. and Wang, M. (2010). The effects of grape seed extract fortification on the antioxidant activity and quality attributes of bread. J. Food chem.,119(1):49-53.

Saatchi, A.; Kadivar, M.;Zad, S. S and Abaee, M.S. (2014). Application of some antifungal and antioxidant compounds extracted from some herbs to be used in cakes as biopreservatives.J.Agr. Sci. Tech., 16:561-568

Schmiele, M.; Jaekel, L.Z.; Patricio, S.M.C.; Steel, C.J. and Chang, Y.K. (2012). Rheological properties of wheat flour and quality characteristics of pan bread as modified by partial additions of wheat bran or whole grain wheat flour. Inter. J. Food Sci. Technol., 47:2141-2150.

Seleem, H.A. and Mohamed, Z.E.O.M. (2014). Influence of some medicinal and aromatic plants addition on pan bread quality.World J. Dairy Food Sci.,9(2):299-307.

Snedecor, G.W. and Cochran, W.G.(1982). Statistical Methods. $6^{\text {th }}$ ed.,Iowa State Univ., Press,Iowa, U.S.A.

Snoussi, M.;Noumi, E.;Punchappady-Devasya, R.;Trabelsi, N.;Kanekar, S.;Nazzaro,
F.;Fratianni, F.;Flamini, G.; De Feo, V. and AlSieni, A. (2018). Antioxidant properties and antiquorum sensing potential of Carumcopticum essential oil and phenolics against Chromobacteriumviolaceum.J.Food Sci. Technol., 55(8):2824-2832.

SoltaniHowyzeh, M.; Sadat Noori, S.A.; Shariati J, V. and Niazian, M. (2018). Essential oil chemotype of Iranian ajowan (Trachyspermumammi L.).J. Essent. Oil Bear. Pl.,21(1):273-276.

Wójcik, M.; Dziki, D.; Biernacka, B.; Różyło, R.; Miś, A. and Hassoon, W.H. (2017). Effect of the addition of mixture of plant components on the mechanical properties of wheat bread. Int.Agrophys. J., 31(4):563-569.

Zarshenas, M.M.;Samani, S.M.;Petramfar, P. and Moein, M. (2014). Analysis of the essential oil components from different Carumcopticum L. samples from Iran.Pharmacognosy Res.,6(1):6266.

Zhu, F.; Sakulnak, R. and Wang, S. (2016). Effect of black tea on antioxidant, textural, and sensory properties of Chinese steamed bread. J. Food Chem., 194:1217-1223. 


\section{تأثير نبات الأجوين على جوده خبز القوالب}

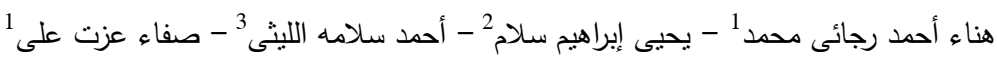

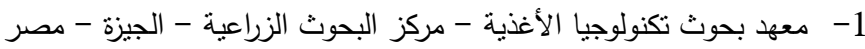

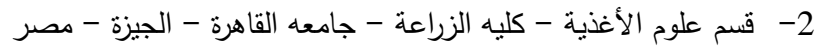

$$
\begin{aligned}
& \text { 3- قسم بساتين الزينة - كليه الزراعة - جامعه القاهرة - الجيزة - مصر الهر }
\end{aligned}
$$

تهدف هذه الدراسـة إلى تقييم تأثير نبات الأجوين وزيته العطرى على جودة خبز القوالب. حيث وجد أن نسـبة الزيت العطرى تصـل إلى 2.7\%، وتم التعرف على مركبات الثيمول 35.80\% والباراثيمين 34.76\% والجاما تربينين 19.20\% كمركبات رئيســية فى الزيت العطرى. وتن

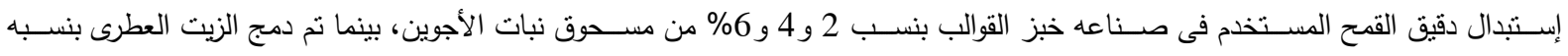
200ميكروليتز/4 جم زيت عباد الثمس. من ناحية مدى القبول العام فكان الإستندال بنسبة 6\% غير مقبول من جانب معظم المحكمين. لم تظهر

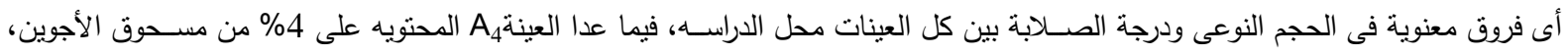

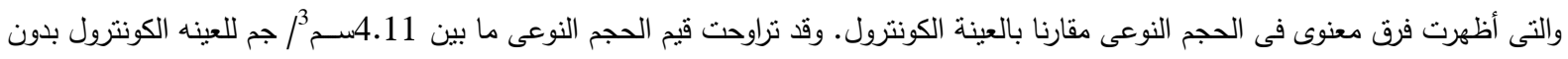

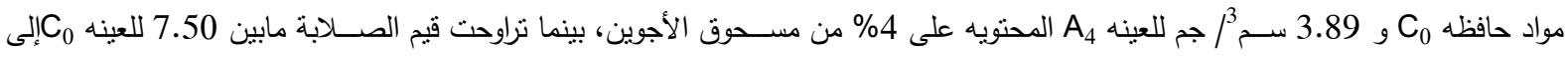

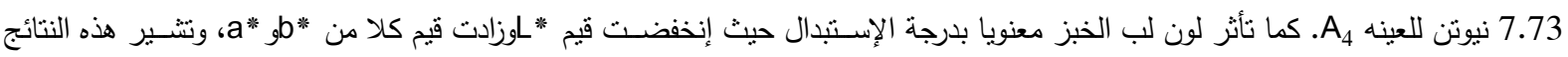

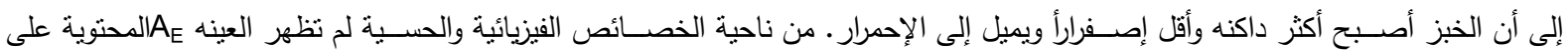

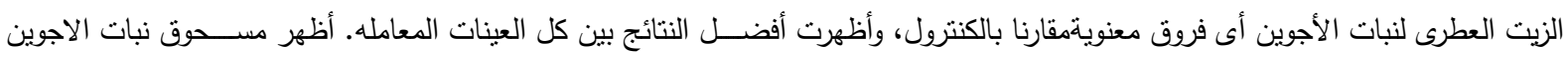

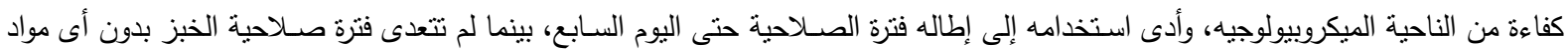

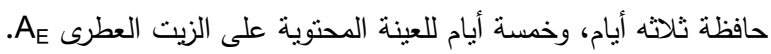
الكلمات المفتاحية: خبز القوالب، نبات الأجوين، الزيوت العطرية، خواص القام القوام، الصفات الصات الفيزيائية، الصلاحية. 
